\title{
The Necessity and Importance of Leisure, Analysis of Factors That Affect Recreating Time, Case Study - Isfahan
}

\author{
Amir Hamzeh Shahbazi (Corresponding author) \\ Ph.D. student of geography and urban planning, \\ Department of Geography and urban Planning, University of Isfahan, Isfahan, Iran \\ Tel: 98-54-1244-3385Ｅ-mail: amir_3_1285@yahoo.com
}

Professor Asghar Zarabi

Department of Geography and Urban Planning, University of Isfahan, Isfahan, Iran

Tel: 98-31-1793-3160_E-mail: aszarrabi@yahoo.com

Professor Masood Taghvayi

Department of Geography and Urban Planning, University of Isfahan, Isfahan, Iran

Tel: 98-31-1793-3160Ｅ-mail: m.taghvaei@ltr.ui.ac.ir

\begin{abstract}
Zeinab Sargazi
Department of Geography and urban Planning

University of sistan and baluchestan, Iran
\end{abstract}

Tel: 98-54-805-6795Ｅ-mail: z.sargazi_ac_48@yahoo.com

\begin{abstract}
Ashkan Shahbazi
MA student in architecture

Department of Architecture Faculty of Architecture University of Tehran
\end{abstract}

Tel: 98-54-805-6795 E-mail: ash_shahbazi@yahoo.com

Received: October 25, 2016 Accepted: December 12, 2016

doi:10.5296/emsd.v6i1.4452 URL: http://dx.doi.org/10.5296/emsd.v6i1.4452 


\section{Macrothink}

\section{Abstract}

This paper aims to study general kinds of leisure time and to analyze their relation with some relevant variables (Demographic, social \& neighborhood Situation). The Necessity of this study is in relation with the role of leisure time on mental and psychic restoring in our todays life. Especially need for intervention and planning on private, Semipublic and public spaces. The goal of the study is to assess and understand the ways that people spent their free time, in their modern life (or nontraditional). The Research method is survey. Data is gathered,by random sampling trough questionnaire that was closed end and was designed and evaluated by the author. Data analysis is based on nonparametric statistic model. The study is an applied research and limited to Isfahan city and Study is conducted based on the hypothesis of the study which is: the ways that people spend their leisure time is regarding their personal, social and neighborhood physical characteristics.

Keywords: Leisure time, Isfahan, Urban spaces, Parks, Trip, Sport

\section{Introduction}

It's more than a Century that Iranian society is changing in social and economic structures and is going to inter a new era. So it's important to study and understand the needs and necessities of new phenomena like leisure time. In fact, activity, vitality and being in open spaces like parks reduces the stress and regenerate and restores the mental power and physical health and helps to lose weight.also it's so important in controlling the heart disease.

\subsection{Importance of the Study}

Lack of documented data regarding the ways and kinds of spending free time and lack of data about affective factors concerning the leisure time of citizens.

\subsection{Aims of the Study}

Determining and analyzing the ways that citizens spend their free time. Of course we try to analyze the independent variables that affect these ways.

\subsection{Hypotheses}

The present study has two hypotheses as follow:

A - There is a significant relationship between the way that citizens spend their free time and their personal and social status.

B - There is a significant relationship between Status of Neighborhoods and Leisure time of their residents

\subsection{The Study Area}

The present study has been done in Isfahan.

\subsection{Methodology}

Regarding the aim of the study it is an applied research. Also it is a field study or survey 
research and the sampling method was two-stage random sampling. In fact, in the first stage of the sampling, a number of neighborhoods in the city of Isfahan were selected randomly as the random clusters in the second stage of the sampling within of the neighborhood A few samples were randomly selected. Instrument for data gathering has been a questionnaire with closed questions, which was designed by researcher and its validity evaluated by the Experts and specialists and has been confirmed. The sample size According to the Cochrane model was about 386 but for better coverage of large neighborhoods, increased to 513 cases.

\section{Literature Review}

Leisure time: Leisure time, relaxing time, free time and recreation are described as the time a person is away from work, and everyday activities and doing business, Also life's necessary activities Such as sleeping, training and... are not in this group (Wikipedia, 2013).

Statistical center of Iran, defines leisure as different activities that lead to vitality, freshness, Happiness and Pleasure. This center which is responsible for gathering and publishing the statistics about leisure and culture of Iran, believes concepts regarding the leisure are subjective and the is not a clear borderline between the obligatory activities and leisure.(statistical center of Iran,2010).

\subsection{Kinds of Leisure and the Importance of Facilities}

Leisure time can be categorized in two groups: Active leisure time and passive leisure time.Active leisure time can provide both of the advantages of leisure which are mental and physical health. This kind of leisure is generally out of home and in interaction with others and can be divided in three groups:

a) Social leisure time: emphasizes on relation with friends, family and Society.

b) Cognitive leisure time: deals with game and exciting mental activities

c) Physical leisure time: includes sports and training (Human Resources and Skills Development Canada, 2013).

Also being near to the facilities is an important factor for physical activities but previous studies have showed that the quantity is even more important than other factors like size and dimensions. In addition previous studies have showed that there is a meaningful relation between providing recreational amenities and trade centers along young and elderly people's walkway and their health condition (Frank et al, 2007).

\subsection{Psychological Health and the Effects of Nature}

Although there is little literature and studies about characteristics of outdoor spaces and mental health, but there are a lot about the relation between nature and mental health( Francis et al,2012; Grahn and Stigsdotter,2003; Korpela et al,2001; Milligan and Bingley,2007; Nielsen and Hansen,2007; Scopelliti and Giuliani,2004; Sugiyama et al,2008; Nordh et al, 2009; Maas,2009; Cattell et al, 2008). 


\subsection{The Availability to Urban Green Spaces or Outdoor Green Spaces}

in the Copenhagen city's strategy has scheduled spaces for about 90 percent of people in distance of 400 meters from their home until 2015(Schipperijn, 2010). About 82 percent of Danish people go to park once a week and about 92 percent go to green spaces or choose it as their path or walkway ( Schipperijn, 2010).

About 67 percent of the Denmark sampled cases are close to the green spaces about 300 meters. So this factor is not a barrier (Schipperijn, 2010). Only 3 percent knew the distance factor as a barrier for going to the parks (; Nielsen and Hansen, 2006). But in Sheffield about 64 percent and in Leicester about 90 percent of people were far from green spaces more than 300 meters (Schipperijn, 2010).

\subsection{Physical Inactivity and Stress in Modern Life and Restoring the Mental Power}

The life style in modern societies is going to be based on inactivity and sitting a lot, so having more stress (Pergams and Zaradic, 2006). In relationship with the Stress and restoring mental power the current situation most of the researches and studies emphasize on the positive relation between spending leisure time in park and green spaces and restoring mental and physical power and reduction of stress (Mitchell and Popham, 2008; Nielsen and Hansen, 2007).

About role of walking in cognitive function, stress, interaction with society, nature and Fun has been said, Walking has great benefits for old people regarding their general health condition (Brach et al, 2003), Enhancement abilities (Simonsick, 2005), stability (Melzeret al, 2003), improving cognitive abilities (Yaffe et al, 2001), coping with stress (Mobily et al, 1996), interaction with nature (Maller et al, 2006), interaction with friends and neighbors (Bertera, 2003), social relationship and mental health (Glass et al, 2006).

Proportion of leisure types in Canada suggests that, social leisure in years 1992, 1998 and 2005 is reported about $1.8,1.9$ and 1.7 hours respectively. However cognitive leisure time is reported to be 1.1, 1.1 and 1.2 hours respectively and physical leisure time was the same in above mentioned years which was 0.5 hour/s (ibid).

\subsection{Four Approach towards Leisure Time}

Theoretically, leisure time has different concepts and definitions regarding viewpoint and approach of the researcher. At least there are four approaches concerning leisure time as follows (Haywood, 2005:18):

d) Temporal approach: leisure time is the time which there is no obligatory work and person doesn't work for money.

e) Activity approach: activities like sport, Watching TV, art, gams, dancing, and entertainments are included in this category.

f) Functional approach: the time in which there were some benefits and advantages for the person. 
g) Approach based on freedom: leisure time is the time in which all the actions are free and optional and there is a relative freedom in social activities (ibid).

\section{Results and Discussion (Data Analysis)}

\subsection{Statistical Findings and Assessment of Leisure Time in the Isfahan}

Statistical results derived from questionnaire showed: About 91 percent of participant provided valid answers for these questions.

- Spending leisure time and watching TV: About 20 percent of participants do not watch National TV programs, about 42.5 percent watch TV about 1 hour or less than an hour. 30 percent watch about 1 to 4 hours and 17 percent watch it more than 4 hours.

- Leisure time and doing Art works: About 20 percent of participants do artworks, of course 16 percent of them do it for less than 2 hours.

- Leisure time and surfing internet: About 42.5 percent of participant use internet in leisure time about 24 percent of 42.5 surf internet for 1 hour and 10 percent did it for 1 to 2 hours and the remaining surf more hours.

- Leisure time and going to parks: 42 percent participants do not go to parks.31 percent go to parks for an hour and 17 percent go for 1 to 2 hours and the others go more than 2 hours.

- Leisure time and going out: about 39 percent of participants do not go out. 34 percent go out about 1 hour or even less. 22 percent answered that go out between 1 to 3 hours. 7 percent go out more than 3 hours.

- Leisure time and doing sport and activities: About 74.4 percent never do sport or activities. 25.5 percent do sport in leisure time. 16 percent of this 25.5 percent do it for less than an hour and 6.5 percent do sports about 1 to 2 hours.

- Leisure time and calling friends and Relatives: 56 percent of participants had positive answer. 18 percent of these participants call friend for half of an hour and 22 percent of them called between 30 minutes to an hour and 8 percent answered that they call between 1 up to 2 hours and 8 percent called more than 2 hours.

\subsection{Statistical Findings and Assessment of Facilities and Urban Open Spaces in Isfahan}

- Going to small neighborhood parks: about 38 percent of participants never or rarely go to these parks. 15 percent said they go once or twice in a month.35 percent go to once or twice in a week and 12.5 go to parks every day.

- Going to grand city parks: about 20 percent of people never go to grand city parks. But 13 percent mentioned that they go every day or twice a week. 18 percent said they go to city parks once a week. Studies showed that there is a meaningful relation between going to small neighborhood parks and going to grand city parks which is significant in level about 0.001 . 


\section{Macrothink}

Environmental Management and Sustainable Development

ISSN 2164-7682 2017, Vol. 6, No. 1

- Going to outdoor game and sport centers in neighborhood: 58 percent of participants mentioned they never do it. 3 percent said they do it every day. Also 17 percent do it once or twice a week.

\subsection{Descriptive Analysis Regarding the Amount of Daily Exercise and Physical Activity}

Amount of daily exercise: 53.6 percent of participant never had physical exercise. Only 30 percent mentioned having exercises, 25 percent of people who had exercise had it only for 30 minutes or less and 13 percent had more than half of an hour.

\subsection{Assessing the General Mental and Psychological Condition of Respondents (According to} Their Opinion)

General psychological condition of participant: 13.3 percent of participant said their mentality is bad or very bad (improper or Very inappropriate). 32.6 percent believed they are in an average psychological condition and finally 54 percent believed they are in good and even best mood.

\section{Results of Inferential Statistics (Testing Hypotheses)}

Considering the nature of data scale (nominal, interval, relative). Appropriate statistical models were used.

\subsection{First Hypothesis}

There is a significant relationship between the way that citizens spend their free time and their personal and social status.

Independent variable $\mathrm{X}: \quad$ Going to the neighborhood park Scale: Ordinal

Dependent variable $\quad \mathrm{Y}$ Not being happy and motivation for recreation and exercise

Statistical method for testing: Chi Square - Kruskal Wallis

Table 4.1. Relationship between not being happy and motivation for recreation and. rate of going to and using neighborhood park

\begin{tabular}{|l|l|l|l|}
\hline Chi-Square Tests & Value & df & Asymp. Sig. (2-sided) \\
\hline Pearson Chi-Square & 28.660 & 16 & .026 \\
\hline Likelihood Ratio & 29.236 & 16 & .022 \\
\hline Linear-by-Linear Association & 3.858 & 1 & .050 \\
\hline N of Valid Cases & 340 & & \\
\hline 1 cell (4.0\%) has expected count less than 5. \\
The minimum expected count is 4.59.
\end{tabular}

Reference: Findings from field study obtained from research questionnaire

Test result: According to data obtained from field study as well as Chi Square - Kruskal Wallis methods, significance level is .026 between dependent and independent variables. 


\subsection{Second Hypothesis}

There is a significant relationship between the Respondents perception of the safety and welfare of women in parks and Going to the neighborhood park

Independent variable X: Respondents' perception of the safety and welfare of women in parks Scale: Ordinal

Dependent variable Y: Going to and using the neighborhood park Scale: Ordinal

Table 1. Relationship between the Respondents' perception of the safety and welfare of women in parks and Going to the neighborhood park

\begin{tabular}{|l|l|l|l|}
\hline & Value & df & Asymp. Sig. (2-sided) \\
\hline Pearson Chi-Square & 30.751 & 16 & .014 \\
\hline Likelihood Ratio & 31.983 & 16 & .010 \\
\hline Linear-by-Linear Association & 6.196 & 1 & .013 \\
\hline N of Valid Cases & 327 & & \\
\hline $\begin{array}{l}\text { 5 cells (20.0\%) have expected count less than } 5 . \\
\text { The minimum expected count is 1.51. }\end{array}$ \\
\hline
\end{tabular}

Reference: Findings of field study obtained from research questionnaire

Test result: According to data obtained from field study as well as Chi Square - Kruskal Wallis methods, significance level is .014 between dependent and independent variables

\section{Conclusion}

The theoretical results showed that leisure time necessarily and primarily include relaxation, enjoyment, recreation, and vitality. So it is independent and apart from activities like every day common activates, business and training. This is the point that is ignored in our society because we consider activities like sleep and training and other daily necessary activities as leisure time. It is emphasized that even passive leisure and free time cannot be useful in restoring and improving health condition of modern human being which is vulnerable shocks and harms due to new robotic and computerized life style.

Clearly, modern life and its consequences, if cannot be combined and mixed with active leisure time and daily exercises will lead to heart diseases, high blood pressures, diabetes, stress and other related health problems and these problems will challenge citizens, private and public sectors.

This is the reason why in countries like Denmark a distance of 400 meters is determined for access of 90 percent of people to parks. and 82 percent of them go to these parks once a week and 92 percent go to other green spaces of the city. Comparing this statistics with the situation in Isfahan we saw 42 percent in Isfahan never go to parks or go once a year. 58 percent answered they rarely do any sport activities and exercises. In addition 42 percent used internet in their free time and 56 percent just used phone to call friend and relatives, off course none of these activates cannot provide necessary physical and mental health so 13 percent of the participants believed they are in very bad or bad mental status. 


\section{Ml Macrothink}

The Chi-square and Kruskal-Wallis models showed a meaningful relationship between not being in good mood and having motivation for going out as the independent variable and going to parks as the dependent variable which was 0.026. Also there was a meaningful relationship between the the Respondents' perception of the safety and welfare of women in parks as the dependent variable and the rate of attending them in parks as the independent variable which was significant in 0.01 .

The findings are a warning for experts, plan makers and managers. Any neglect regarding leisure and free time will lead to irreparable consequences; in addition economic savings in this situation will lead to big expenses for treatment of physical and mental health problems of citizens in long term.

\section{References}

Bertera, E. M. (2003). Physical activity and social network contacts in community dwelling older adults, Activities, Adaptation and Aging, 27(5), 113-127. doi: 10.1300/J016v27n03_08

Cattell, V., Dines, N., Gesler, W., \& Curtis, S. (2008). Mingling, observing, and lingering: everyday public spaces and their implications for well-being and social relations. Health \& Place, 14(3), 544-561.

Francis, J., \& Wood, L., \& Knuiman, M., \& Giles-Corti, B. (2012). Quality or quantity? Exploring the relationship between Public Open Space attributes and mental health in Perth, Western Australia, Social Science \& Medicine, 74(10),1570-1577, http://dx.doi.org/10.1016/j.socscimed.2012.01.032. Epub 2012 Mar 13.

Frank, L., Kerr, J., Chapman, J., \&Sallis, J. (2007) Urban Form Relationships With Walk Trip Frequency and Distance Among Youth, American Journal of Health Promotion, 4(21), 305-311

Glass, T. A., DeLeon, C. F., Bassuk, S. S., \& Berkman, L. F. (2006).Social engagement and depressive symptoms in late life - longitudinal findings, Journal of Aging and Health, 18(4), 604-628

Grahn, P., \& Stigsdotter, U. A. (2003). Landscape planning and stress, Urban Forestry \&Urban Greening, 2(1), 1-18. http://dx.doi.org/10.1078/1618-8667-00019

Human Resources and Skills Development Canada. (2013). Departmental Performance Report, http://www.hrsdc.gc.ca

Korpela, K. M., Hartig, T., Kaiser, F. G., \&Fuhrer, U. (2001). Restorative experience and self-regulation in favorite places, Environment and Behavior, 33(4), 572-589

Maas, J., van Dillen, S. M. E., Verheij, R. A., \& Groenewegen, P. P. (2009). Social contacts as a possible mechanism behind the relation between green space and health, Health \& Place, 15(2), 586-595.

Maller, C., Townsend, M., Pryor, A., Brown, P., \& St Leger, L. (2006). Healthy nature healthy people:'contact with nature' as an upstream health promotion intervention for populations, 
Health Promotion International, 21(1) ,45-54.

Melzer, I., Benjuya, N., \& Kaplanski, J. (2003). Effects of regular walking on postural stability in the elderly, Gerontology, 49(4), 240-245.

Milligan, C., \& Bingley, A. (2007). Restorative places or scary spaces? The impact of woodland on the mental well-being of young adults. Health \& Place, 13(4), 799-811

Mitchell, R., \& Popham, F. (2008). Effect of exposure to natural environment on health inequalities: an observational population study. Lancet, 372, 1655-1660.

Mobily, K. E., Mobily, L. M., Rubenstein, J. H., Lemke, M. W., \& O’Hara, R. B. (1996). Wallace, Walking and depression in a cohort of older adults: the Iowa 65+ Rural Health Study, Journal of Aging and Physical Activity, 4(2), 119-135.

Morrison, D. F. (1976). Multivariate StatisticalMethods, seconded.McGraw-Hill, New York

Nielsen, T. S., \& Hansen, K. B. (2007). Do green areas affect health? Results from a Danish survey on the use of green areas and health indicators. Health \& Place, 13(4), 839-850 http://dx.doi.org/10.1016/j.healthplace.2007.02.001

Nielsen, T. S., \& Hansen, K. B. (2006). Nearby nature and green areas encourage outdoor activities and decrease mental stress. $\mathrm{CAB}$ reviews: perspectives in agriculture, veterinary science. Nutrition and Natural Resources 1(no) 059.

http://dx.doi.org/10.1079/pavsnnr20061059

Nordh, H., Hartig, T., Hagerhall, C. M., \& Fry, G. (2009). Components of small urban parks that predict the possibility for restoration. UrbanForestry \& Urban Greening, 8(4), 225-235. http://dx.doi.org/10.1016/j.ufug.2009.06.003

Pergams, O. R. W., \& Zaradic, P. A. (2006). Is love of nature in the US becoming love of electronic media? 16-year downtrend in national park visits explained by watching movies, playing video games, internet use, and oil prices, Journal of Environmental Management, 80(4), 387-393. http://dx.doi.org/10.1016/j.jenvman.2006.02.001

Schipperijn, J., Ekholm, O., Stigsdotter, U., Toftager, M., Bentsen, P., Jørgensen, F. K., \& Randrup, T. B. (2010). Factors influencing the use of green space: Results from a Danish national representative survey Landscape and Urban Planning, 95, 130-137. http://dx.doi.org/10.1016/j.landurbplan.2009.12.010

Rapoport, R., Robert, N., \& Rapoport, R. N. (1974). Four Themes in the Sociology of Leisure, The British Journal of Sociology, 25(2), 215-229. http://dx.doi.org/10.2307/589313

Scopelliti, M., \& Giuliani, M. V. (2004). Choosing restorative environments across the lifespan: a matter of place experience. Journal of Environmental Psychology, 24(4), 423- 437. http://dx.doi.org/10.1016/j.jenvp.2004.11.002

Simonsick, E. M., Guralnik, J. M., Volpato, S., Balfour, J., \& Fried, L. P. (2005). Just get out the door! Importance of walking outside the home for maintaining mobility: findings from the Women's Health and Aging Study, Journal of the American Geriatrics Society, 53(2), 
198-203.

Sugiyama, T., Leslie, E., Giles-Corti, B., \& \& Owen, N. (2008). Associations of neighborhood greenness with physical and mental health: do walking, social coherence and local social interaction explain the relationships? Journal of Epidemiology and Community Health, 62(5), 9.

Yaffe, K., Barnes, D., Nevitt, M. D., Lui, L. Y., \& Covinsky, K. (2001). A prospective study of physical activity and cognitive decline in elderly women: women who walk, Archives of Internal Medicine, 161(14), 1703-1708.

\section{Copyright Disclaimer}

Copyright for this article is retained by the author(s), with first publication rights granted to the journal.

This is an open-access article distributed under the terms and conditions of the Creative Commons Attribution license (http://creativecommons.org/licenses/by/3.0/). 